\title{
СЕДИМЕНТАЦИОННЫЕ МОДЕЛИ ПОДСОЛЕВЫХ КОМПЛЕКСОВ ЮЖНОГО БОРТА ПРИКАСПИЙСКОГО ОСАДОЧНОГО БАССЕЙНА В ПОЗДНЕМ ПАЛЕОЗОЕ
}

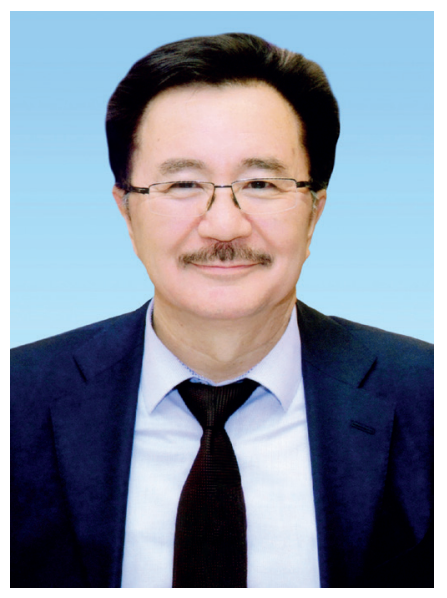

Х.Б. АБИЛХАСИМОВ доктор геол.-мин. наук, академик Академии минеральных ресурсов РК,

PAE, генеральный директор, https://orcid.org/0000-0002-4518-0055

ТОО «ГЕО-МУНАЙ XXI»

Республика Казахстан, 050050, г. Алматы, ул. Панфилова 110, офис 205

Приводятся результаты литологических исследований и палеогеограффических реконструкций позднепалеозойского этапа развития и особенностей формирования осадочных фрормаций южного борта Прикаспийского осадочного бассейна. Сложное геологическое строение региона обусловлено, главным образом, влиянием тектонических, вулканических и денудационных процессов на осадконакопление, которые происходили в зоне сочленения области кряжа Карпинского, Донбасско-Астраханской зоны, Северного Устюрта и Урала.

Блоковая структура фундамента значительно влияло на продолжительность этапов седиментации и фрормирование как карбонатных платформ, так и зон с преимущественно терригенным накоплением осадков. Различные глубины залегания фрундамента, определяют изменчивость литологического состава и мощностей отложений палеозоя. Проведена типизация разрезов карбонатных платформ в пределах бортовых зон Прикаспийской впадины, которая позволила выявить связь условий осадконакопления и блоковой структуры фундамента.

КЛЮЧЕВЫЕ СЛОВА: Прикаспийский осадочный бассейн, седиментационная модель, обстановки осадконакопления, Тенгиз-Кашаганская, Астраханская, Южно-Эмбинская, карбонатные платформы, поздний палеозой, карбонатно-терригенный.

\footnotetext{
* Адрес для переписки. E-mail: khairly59@mail.ru
} 


\title{
КАСПИЙ МАНЫ ШӨГІНДІ БАССЕЙНІНІН ОНТҮСТІК БӨЛІГІНІН КЕШ ПАЛЕОЗОЙДАҒЫ ТҰЗ АСТЫ КЕШЕНДЕРІНІН СЕДИМЕНТАЦИОНДЫҚ МОДЕЛЬДЕРІ
}

Х.Б. ӘБІЛХАСЫМОВ, доктор геол.- ғылым мин., ҚР Минералдық ресурстар академиясының академигі, PAE, бас директор, https://orcid.org/0000-0002-4518-0055

\author{
«ГЕО-МҰНАЙ XXI» ЖШС \\ Қазақстан Республикасы, 050050, Алматы қ., Панфилов к-сі, 110, офис 205
}

Кеш палеозой кезеңінің литологиялық зерттеулері мен палеогеографриялық қайта құру нәтижелері және Каспий маңы шөгінді бассейнінің оңтүстік бөлігінің түзілімдерінің ерекшеліктері келтірілген.

Күрделі геологиялық аймақтың құрылымы негізінен Карпинский жотасы, ДонбассАстрахань аймағы, Солтүстік Үстірт және Оралдағы тектоникалық, вулкандық және денудациялық процестерінің пайда болған шөгінділерге әсер етуіне байланысты болуда

Іргетастың блок құрылымы тұндыру кезеңдерінің ұзақтығына және негізінен терригендік жауын-шашын жиналатын карбонатты платформалардың да, аймақтардың да қалыптасуына айтарлықтай әсер етті. Іргетастың әртүрлі тереңдігі, палеозой шөгінділерінің литологиялық құрамы мен қуаттарының өзгергіштігін анықтауға мүмүкіндік берді. Шөгу жағдайларының байланысын анықтауға мүмкіндік берген Каспий маңы ойпаты мен іргетастың блок құрылымы бөліктік аймақтар шегінде карбонатты платформалардың тілімдерін типтеуі жүргізілді.

ТҮЙІн сөзДЕР: Каспий маңы шөгінді бассейні, шөгу моделі, Теңіз-Қашаған, Астрахань, Оңтүстік Ембі, карбонатты платформалар, кеш палеозой, карбонатты-терригенді.

\section{SEDIMENTATION MODELS OF SUBSALT COMPLEXES OF THE SOUTHERN BOARD OF THE PRE-CASPIAN SEDIMENTARY BASIN IN THE LATE PALEOZOIC}

KH.B. ABILKHASIMOV, Dr. Sci. in Geology and Mineralogyю academician of the Academy of Mineral Resources of the RK, RANH, Director general, https://orcid.org/0000-0002-4518-0055

\section{GEO-MUNAY XXI LLP}

110, Panfilov st., office 205, Almaty, 050050, Republic of Kazakhstan

The results of lithological research and paleogeographic reconstructions of the Late Paleozoic development stage and the peculiarities of the formation of sedimentary layers in the southern board of the Pre-Caspian sedimentary basin are presented. The compound geological structure of the region is mainly due to the influence of tectonic, volcanic and denudation processes on sedimentation, which took place in the junction zone of the Karpinsky ridge, Donbass-Astrakhan zone, Northern Ustyurt and the Urals.

The block structure of the basement significantly influenced the duration of sedimentation stages and the formation of both carbonate platforms and zones with predominantly terrigenous sediment accumulation. Different depths of the basement, determine the variability of the lithological composition and thickness of the Paleozoic deposits. The typification of the sections of carbonate platforms within the board zones of the Pre-Caspian basin was carried out, which made it possible to identify the ties between the conditions of sedimentation and the block structure of the basement.

KEY WORDS: Pre-Caspian sedimentary basin, sedimentation model, sedimentation environments, Tengiz-Kashagan, Astrakhan, South Emba, carbonate platforms, Late Paleozoic, carbonate-terrigenous. 
ля интерпретации этапов седиментации осадочных бассейнов многими исследователями используется модель так называемой «карбонатной платформы», которая характеризуется последовательно сменяемыми фациальными поясами: от мелководья переходной приливной равнины, внутренней шельфовой лагуны, внутриморской песчаной отмели окраины, через карбонатный склон и рифовые комплексы в сравнительно глубоководную бассейновую впадину (депрессию). В международной геологической практике такие образования получили название как изолированные карбонатные подводно-морские горы и наиболее близким по смыслу в русскоязычной геологии является термин «карбонатный массив».

Сами карбонатные массивы почти нацело сложены разнофациальными известняками и доломитами, окрашенными преимущественно в светлые тона, с прослоями вулканогенно-терригенного и терригенного материала. Отложения, развитые по обрамлению карбонатных массивов с конденсированным (сравнительно маломощным) разрезом, представлены темноцветным карбонатно-глинистым и карбонатно-терригенным, а в более удаленных частях бассейна - тонкослоистым глинисто-сланцевым и терригенным материалом.

В такой модели рифы как органогенные постройки являются одной из составных частей карбонатной платформы.

Развитие карбонатных массивов Прикаспийского осадочного бассейна в палеогеографическом отношении определялось их расположением в зоне сочленения структур юго-восточной окраины Восточно-Европейской платформы с Уральским палеоокеаном и Палео-Тетисом $[1,2]$.

При этом заложение Тенгиз-Кашаганской карбонатной платформы было связано с периодом раскрытия Уральского палеоокеана. Это обусловило более широкий стратиграфический диапазон и более значительные мощности карбонатных отложений. В противоположность этому, зарождение Южно-Эмбинской карбонатной платформы произошло в период закрытия Уральского палеоокеана и связано с относительно кратковременным процессом обмеления территории (период сжатия). Эти же причины обусловили и разную степень сохранности и морфологической выраженности рассматриваемых структур [3,4].

Методика исследований. В основу создания седиментационных моделей Прикаспийского осадочного бассейна нами положен классический формационный анализ, в котором отражены главнейшие признаки: литологический состав, обстановки накопления, толщины.

Цель исследований. Комплексное исследование формаций подсолевых комплексов и создание седиментационных моделей позднепалеозойского этапа эволюции юга Прикаспийского осадочного бассейна.

\section{Обстановки осадконакопления}

Проведенный автором литолого-фациальный анализ подтверждает палеогеографические построения и доказывает, что Центрально-Прикаспийская депрессия на протяжении всей истории своего развития представляла собой наиболее погруженную часть бассейна седиментации, где были сосредоточены глубоководные и наиболее удаленные от источников сноса фации осадков. В бортовых зонах развиты карбонатные платформы, рифовые массивы. Активное поступление обломочного 
материала обеспечивается мощными палеорусловыми системами, которые образуют клиноформы, обращенные вглубь впадины. Сложный, длительный и разнонаправленный процесс формирования осадочного комплекса Прикаспийской впадины отражен на составленных автором литолого-палеогеографических схемах [5-8].

Позднедевонско-ранневизейская седиментационная модель соответствует этапу раскрытия Центрально-Прикаспийского рифта, которая сопровождалась образованием узкого глубокого пролива Уральского палеоокеана. В пределы впадины конусами выноса с Урала через Центрально-Прикаспийский рифт привносилось огромное количество терригенного материала, представленного осадочно-вулканогенными, кремнисто-глинистыми отложениями и базальтами. Накопление мощных терригенных толщ в области Южно-Эмбинского (Тугаракчанского) рифта вовлекло юго-восточную периферию Прикаспийского бассейна в устойчивое компенсированное прогибание.

В пределах Южно-Эмбинского поднятия карбонатных построек не обнаружено. Это связано с формированием в этой части бассейна мощных конусов выноса, которые привносили большой объем терригенного материала. Здесь получили развитие горноприбрежные терригенные отложения, которые заполнили, по всей вероятности, пограничные миогеосинклинальные троги и опущенные части платформы. Об этом свидетельствуют данные бурения и сейсмики. Сжатия привели в позднем визе к воздыманию и постепенному обмелению, поэтому в это время песчано-алевритово-глинистые осадки формировались в мелководной обстановке. Такая закономерность нами была установлена для южных частей Южно-Эмбинской зоны.

Важно отметить, что из вскрытых бурением разрезов юго-восточной части Прикаспийской впадины наиболее древними являются отложения франского и фаменского ярусов.Они вскрыты на Южно-Эмбинском поднятии на структурах: Жанасу (Г-10, Г-11), Туресай (Г-7), Северный Мынсуалмас (П-1, П-2, П-3). Толщина характеризуемой толщи в разрезе скважины П-1 (Северный Мынсуалмас) - 2100 м. Разрез представлен аргиллитами, песчаниками, конгломератами. Франский ярус верхнедевонских отложений скважины Г-11 (Жанасу) содержит в себе прослои мергелей и известняков. Вскрытая толщина верхнего девона здесь 760 м. К верхнедевонской терригенной толще отнесена и флишеподобная толща песчаников, алевролитов, аргиллитов разреза скважины Г-6. В глубокой скважине на площади Тасым Юго-Восточный (Г-1, забой 7050 м.) также вскрыты отложения карбонатно-терригенного состава. В интервалах 6907-6936, 6872.2-6889.2, 6943-6970 м. нижнекаменноугольные отложения представлены неравномерным переслаиванием прослоев средне сцементированного песчаника, глин и плотных карбонатизированных разностей.

Литологические исследования разрезов скважин позволили выделить, кроме собственно платформенных фаций, также сопровождающие их миогеосинклинальные терригенные и терригенно-карбонатные молассоидные и флишоидные породы. Наличие грубообломочного материала, эффузивов, плохо окатанных обломков, обугленного детрита свидетельствует о близости источника сноса.

Таким образом, следует отметить, что основной особенностью осадконакопления в пределах юго-восточного борта Прикаспийской впадины является привнос терригенного материала, который не способствовал формированию карбонатных отложений [8]. 
В пределах южного борта осадочного бассейна, куда не доходили гравитационные потоки, был спокойный тектонический режим, что способствовало зарождению позднефранско-раннетурнейской карбонатной платформы. Карбонатный этап осадконакопления, начавшийся в девоне на большей части обрамления юга Прикаспия, без резких фациальных изменений продолжался и в каменноугольном периоде.

На литолого-палеогеографической схеме (рисунок 1) показано, что в южной части бассейна - в позднедевонское время сформировалась обширная карбонатная Астраханско-Жылыойская девонская карбонатная платформа.

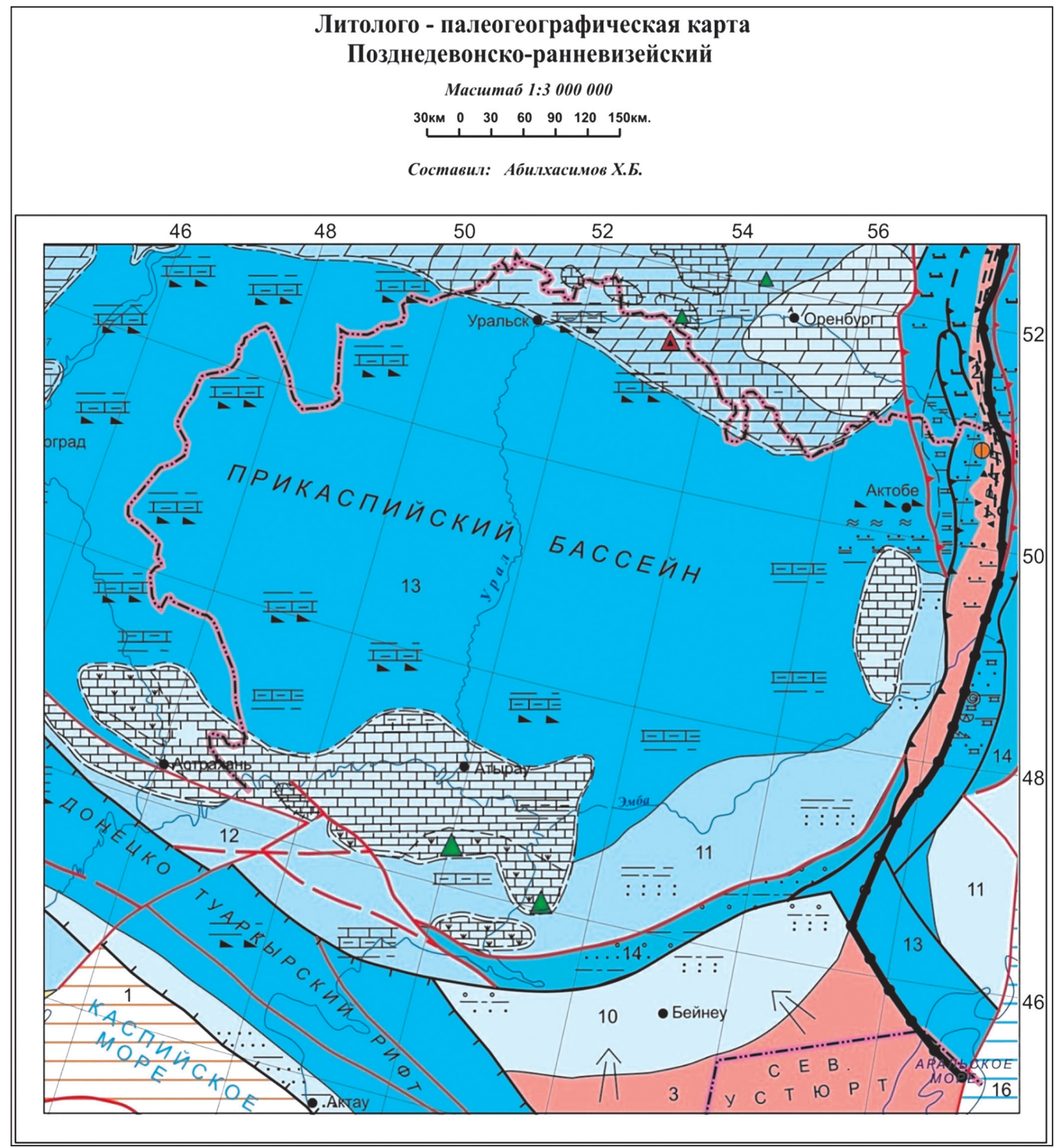

Рисунок 1 - Литолого-палеогеографическая карта позднедевонско-ранневизейского этапа (условные обозначения на рисунке 9). Составил Х.Б. Абилхасимов 
На сейсмических профилях она оконтуривается по прослеживанию ее цоколя между региональными отражающими горизонтами $\Pi_{3}$ и П. Предполагаемый возраст карбонатных, карбонатно-терригенных отложений, заключенных между этими горизонтами, средний-ранний девон.

На этом цоколе происходил рост рифогенных построек позднедевонско-каменноугольного возраста: Астраханская, Имашевская, Котяевская, Жамбай, Бахиридин, Караколь, Кашаган, Тенгиз, Южная, Королевское, Огай, Каратон, Пустынная, Тажигали, Актоты и других. Наряду с указанными карбонатными постройками менее рельефно выражены карбонатные постройки верхнедевонско-башкирского возраста, такие как Ансаган, Аманат, Буйыргын, Максат, Северный Култук и Прорва Глубокая.

Карбонатные отложения Тенгиз-Кашаганской карбонатной платформы охватывают широкий стратиграфический интервал - от начала позднего франа (по данным бурения на структуре Ансаган (рисунок 2) и сейсморазведочных работ на структурах Пустынная, Тажигали и Максат) до среднего карбона [4].

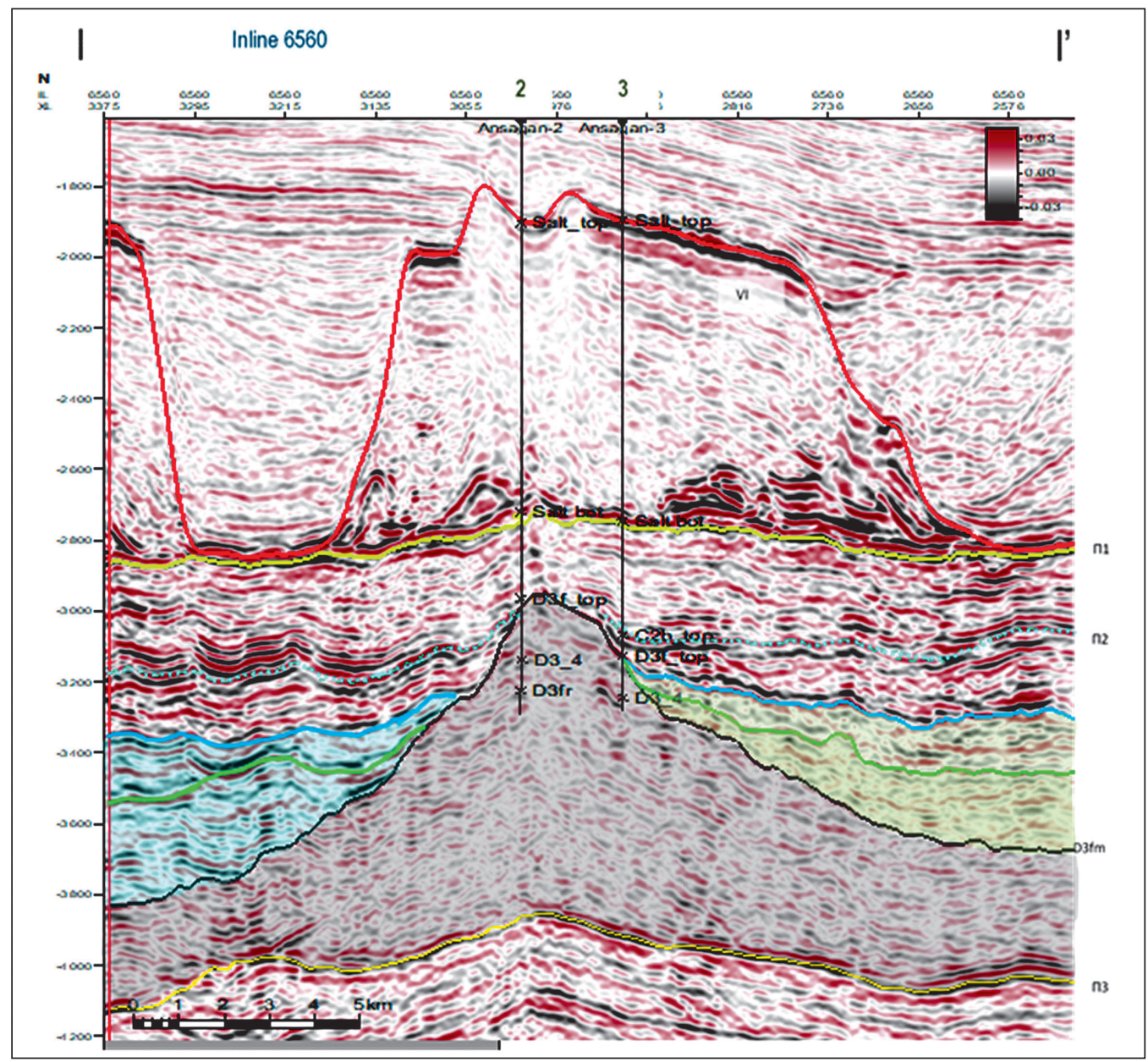

Рисунок 2 - Девонская карбонатная постройка Ансаган 
В ее составе выделяются два структурных этажа - верхнедевонско-нижнетурнейский и каменноугольный, разделенные кратковременным стратиграфическим перерывом, время проявления которого определяется как середина турне.

В пределах Октябрьской тектонической ступени Восточно-Междуреченского блока, по палеозойской поверхности выделяется обширное карбонатное тело, названное Центральный Бахаридин, примыкающее на северо-западе к Кобяковской структуре, а на юго-западе - к структуре Алга [8]. Данная структура осложнена серией разноориентированных локальных поднятий, в центре которой выделяется карбонатная постройка, вытянутая в северо-западном направлении. Ее размеры по изогипсе -5750 м составляют около $20.0 \times 6.0$ км с амплитудой локальных поднятий более 300 м. Пробуренная скважина КБ-101 (Каратобе-Бурбайтал) вскрыла мощную толщу отложений нижнепермского, карбонового и позднедевонского возраста,представленных карбонатно-сланцево-аргиллитовыми породами. Ближе к забою скважины были обнаружены раковинные органические остатки франского яруса низов верхнего девона. Также здесь были обнаружены мелкие однокамерные фораминиферы девонского облика.

В пределах Астраханской карбонатной платформы наиболее древние отложения нижнего девона, скорее всего, их базальная часть, вскрыты только скважине Девонская-2 в интервале 7003-6550 м [2]. Эти отложения рассматриваются как осадки склонов вулканических построек центрального типа и продукты их переотложения и смешения с терригенным обломочным материалом из подстилающих более древних толщ в мелководной и прибрежно-морской обстановках. Мощность отложений нижнего девона изменяется от 150 до 500 м.

Во второй половине раннего девона и начале среднего в пределах вулканического поднятия Астраханского свода постепенно начала затухать вулканическая деятельность $[3,11,12]$. В результате мелководные осадки сменились более глубоководными, а на вулканических постройках начали формироваться карбонатные шапки биогермов. Продуктами разрушения и частичного размыва биогенных построек являются калькарениты турбидитного происхождения, кальцилютиты и шламовые известняки, вскрытые скважинами. Сами биогермы оконтурены нами лишь по сейсмическим данным.

После затухания вулканической деятельности раннего-среднего девона, структурной перестройки, приведшей к поднятию и размыву южной части Астраханского свода в конце среднего девона, осадконакопление возобновилось в начале франа. Интересно отметить, что в области относительно глубоководной седиментации оказалась и зона размыва конца среднего девона. По всей вероятности, это связано с процессами растяжения и погружения в зоне рифтогенеза кряжа Карпинского [3].

В области мелководной седиментации среди нижнефранских отложений мощностью 100-300 м различаются две фации: биогенных карбонатных построек типа ракушняковых банок и мелководных преимущественно алевро-глинистых и карбонатно-обломочных отложений. Фация биогенных построек вскрыта в скважине Девонская-1 (интервал 6087-6096 м) и Девонская-3 (интервал 5994-6057 м). В скважине Девонская-1 она представлена полностью доломитизированными биогенными и биокластовыми известняками типа ракушняка с послойным расположением 
целых крупных разрозненных раковин замковых брахиопод и их обломков, а также одиночных кораллов. В фации мелководных карбонатно-глинистых и карбонатно-обломочных пород различаются две субфации, характеризующие, с одной стороны, проксимальные склоны ракушняковых банок, с другой - дистальные части склонов и депрессии между банками.

В среднем фране продолжалась трансгрессия и дифференцированное погружение Астраханского поднятия, начавшиеся в раннем фране, что привело к почти полному выравниванию фациальных обстановок как в пределах Астраханского поднятия, так и прилегающих частях акватории.

В результате на месте ранне-среднедевонского вулканического Астраханского поднятия возникла внутрибассейновая карбонатная платформа субширотного простирания с крутым северным и более пологим западным и южным склонами, развивавшаяся в регрессивном режиме в обстановке погружения вплоть до конца турнейского времени раннего карбона. В результате на отдельных участках платформы за рассматриваемый период времени накопилось до 1600 м карбонатных отложений.

Полное отсутствие в составе осадков терригенного материала свидетельствует об изолированности карбонатного плато и о его приподнятом положении в рельефе дна Каспийского бассейна. В современной структуре ее южный склон частично срезан разломом пермского возраста. Среди карбонатных отложений платформы нами выделено две фации: карбонатных биогенных построек и мелководных карбонатно-обломочных отложений. Внутри последней выделено две субфации, характеризующие обстановки с пассивным и активным гидродинамическими режимами накопления.

Таким образом, в позднем девоне на юге Прикаспийского осадочного бассейна сформировалась приподнятая поверхность поднятия, на которой с середины франского века позднего девона до раннетурнейского века раннего карбона формировались мелководные карбонатные осадки карбонатной платформы.

В каменноугольном структурном этаже выделяются два комплекса - турне-нижневизейский и окско-башкирский, разделенные вулканогенно-осадочной пачкой тульского возраста, которые являются уверенно прослеживаемым геофизическим репером между карбонатными массивами.

В конце раннего турне фиксируется перерыв в осадконакоплении. В позднем турне на Тенгиз-Кашаганской платформе начались вертикальные движения, которые привели к образованию поднятых и опущенных блоков (структур). Тенгизский блок был поднятием. На этом поднятии и его периферии, также как и на Каратонском и Королевском поднятиях, в позднем турне и раннем визе формировалась фация иловых холмов.

В конце турнейского века вследствие движения на север Карабогаз-Каракумской и Северо-Каспийской системы микроплит произошло сближение Северо-Устюртского блока с краем Восточно-Европейской платформы. Интенсивные деформации сжатия привели к расколу платформенного основания терригенного клина и образованию конседиментационных складок в верхнедевонско-нижнетурнейском терригенном комплексе Южно-Эмбинской зоны. 
По результатам проведенных комплексных литолого-фациальных исследований выделяются конусы выноса. В пределах Южно-Эмбинского поднятия - Шолькаринский, Тортайский, Восточно-Табынайский и Арман-Аиршагыльский. Исследования глинистых минералов подсолевых отложений юго-востока Прикаспийской впадины, проведенных автором, выявили, что в их распределении существует определенная зависимость от гидрохимического и гидродинамического режимов осадконакопления. Минералогический состав глинистых минералов показывает, что они формировались на суше в условиях жаркого гумидного климата в корах выветривания линейного типа по различному составу пород. В восточной части - по породам основного и ультраосновного состава, по наличию в глинистой ассоциации нонтронита, палыгорскита и клинохризотила (ультрабазитовый массив южного Урала). Наличие горизонта с высоким содержанием палыгорскита указывает на близкий источник сноса, поскольку в более отдаленных от берега участках бассейна тончайшие индивиды палыгорскита при незначительном увеличении путей переноса легко разрушаются. В Арман-Аиыршагыльской зоне, юго-западной части Южно-Эмбинского поднятия и в Тенгиз-Кашаганской зоне характерны глинистые ассоциации с преобладанием гидрослюд и смешаннослойных минералов. Особенностью является наличие туфогенных глин корренситового состава в разрезах площадей Восточный Арман, Арман, Сазтобе и Тенгиз. Состав обломочного материала вулканогенный, андезитовый, встречаются прослои литовитрокластических туфов [5].

В юго-восточной части Прикаспийской впадины широкое проявление андезитового вулканизма в предокское время связывается с деятельностью одиночных вулканов непосредственно в области Арман-Аиыршагыльской зоны. Терригенный материал в пределы Прикаспийской впадины по-прежнему привносился по уже сформированным конусам выноса. В разрезах Южно-Эмбинского типа на площадях Тортай, Молодежная, Табынай, Южно-Эмбинская, Южно-Молодежная, Равнинная и других характерна монтмориллонит-гидрослюдисто-смешаннослойная ассоциация, образованная в корах выветривания по вулканогенно-осадочным породам основного и среднего составов, возможно, девонского возраста, которые вскрыты бурением в Жанасу-Мынсуалмасской горно-прибрежной зоне, близкой к Северному Устюрту. Данный факт подтверждает близость Северо-Устюртского микроконтинента в девоне. Грубозернистые отложения занимают более широкую площадь, чем сами палеорусла в прибрежно-морской зоне в результате миграции русел. Прямые русла также испытывают миграцию, что мы и наблюдаем в разрезе площади Тортай. Области распространения подводно-русловых отложений отмечаются на площадях Жанасу, Туресай, Тортай, Равнинная, где они сложены переслаиванием гравелитов, реже - конгломератов с алевролитами и аргиллитами. Наблюдается ритмичность подводно-русловых течений во времени.

Итак, в конце раннего визе был завершен важный этап в формировании собственно Прикаспийского бассейна: Южно-Эмбинское инверсионное поднятие и Северо-Устюртский микроконтинент ограничили бассейн с юго-востока.

Со второй половины визе начинается новый этап в формировании карбонатных платформ Прикаспийской впадины, значительно отличавшийся от предшествующего этапа, как по сути процессов карбонатной седиментации, так и по месту локализации карбонатных платформ. 


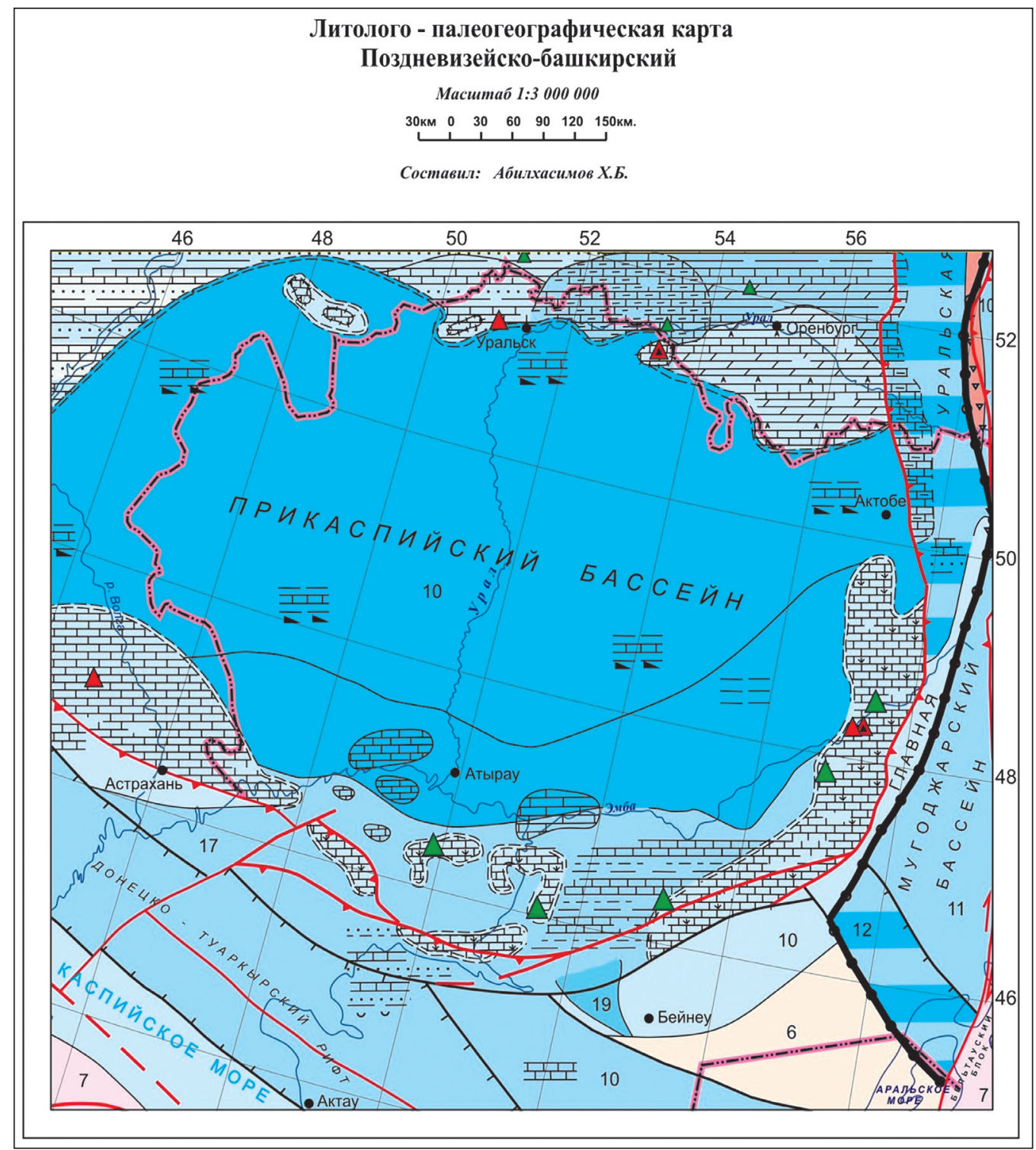

Рисунок 3 - Литолого-палеогеографическая карта поздневизейско-башкирского этапа (условные обозначения на рисунке 9). Составил: Х.Б. Абилхасимов

Поздневизейско-башкирская седиментационная модель. В поздневизейское время помимо Астраханской и Тенгиз-Кашаганской карбонатной платформы, из-за трансгрессии моря бассейн значительно расширился в сторону Северного Устюрта, и граница платформы проходила с востока на запад (рисунок 3).

На юге, в пределах Тенгиз-Кашаганской карбонатной платформы, в позднем визе (алексинское и михайловское время) на поверхности иловых холмов формировались криноидные и брахиоподово-криноидные банки. Иловые холмы образовали палеогеоморфологические возвышенности, на которых криноидные и брахио- 
подово-криноидные банки в свою очередь создали твердый субстрат для рифов. Карбонатный массив, включающий западный и восточный участки Кашаганской платформы, представляет собой единое крупное поднятие, оконтуренное замкнутой изогипсой -5000 м по отражающему горизонту П2, приуроченному к кровле башкирских отложений среднего карбона. Размер его по длинной северо-восточной оси составляет 70 км. В средней своей части ширина карбонатной платформы составляет 8-10 км и расширяется как на западе, так и востоке почти в два раза. Краевые части платформы осложнены узкими линейными или изометричными поднятиями амплитудой до 300 м - римовым обрамлением. Наиболее протяженно рим выражен в крайней северо-восточной части структуры Кашаган $[9,10]$.

С конца позднего визе (веневское время) и в серпуховском веке существовал атолл с фациями рифа. В зарифовой зоне формировались фации биостромов, органогенных банок и отмелей, известковых илов лагуны. Время с раннего визе до серпуховского века, с начала образования холмов, затем криноидных банок и рифов было этапом компенсированного прогибания Тенгизского конседиментационного поднятия. В это время, на границе раннего и позднесерпуховского времени, а также протвинским и запалтюбинским, установлены перерывы.

В башкирский век (с краснополянского до прикамского времени включительно) формировались биокластические банки, отмели и подводные валы. На границе серпуховского и башкирского веков фиксируется перерыв - наступили обмеление и прекращение рифообразования. В отложениях башкирского века установлены небольшая высота банок, размыв и частые поверхности перерывов. Карбонатные отложения Тенгиз-Кашаганской карбонатной платформы охватывают широкий стратиграфический интервал - от начала позднего франа до среднего карбона. Особенность цикла на Тенгизском поднятии состоит в том, что рифообразование здесь прекратилось в конце серпуховского века.

Это могло быть связано с тем, что в башкирский век прекратилось компенсированное прогибание, столь необходимое для существования рифов. На рисунке 4 приведен вертикальный фациальный ряд Тенгиз-Кашаганской платформы.

Поздневизейско-сакмарская прибрежно-морская шельфовая карбонатная толща получила развитие и в зоне Южно-Эмбинского поднятия. Толща представлена разрезами скважин Сарыкум, Уртатау-Сарыбулак, Бекбулат, СазтобеЮжное, Туресай, Тортай (Г-23, Г-12), Южно-Молодежная и Южно-Эмбинская, пробуренных на северо-западном склоне Южно-Эмбинского поднятия.

Ее аналог встречается вдоль восточного борта, где расчленяется на две карбонатные толщи терригенными осадками низов подольского горизонта московского яруса. Карбонатные разрезы Южно-Эмбинского поднятия различаются по стратиграфической полноте, содержанию терригенных прослоев и структурно-генетических типов карбонатных осадков. Накопление карбонатных осадков происходило в мелководном прибрежном морском бассейне в условиях, благоприятных для карбонатной седиментации.

Толщина каменноугольной части толщи в разрезе площади Туресай - 1043 м. Нижняя карбонатная толща сложена известняками различных генетических типов, в различной степени доломитизированных, рассланцованных и массивных с раз- 


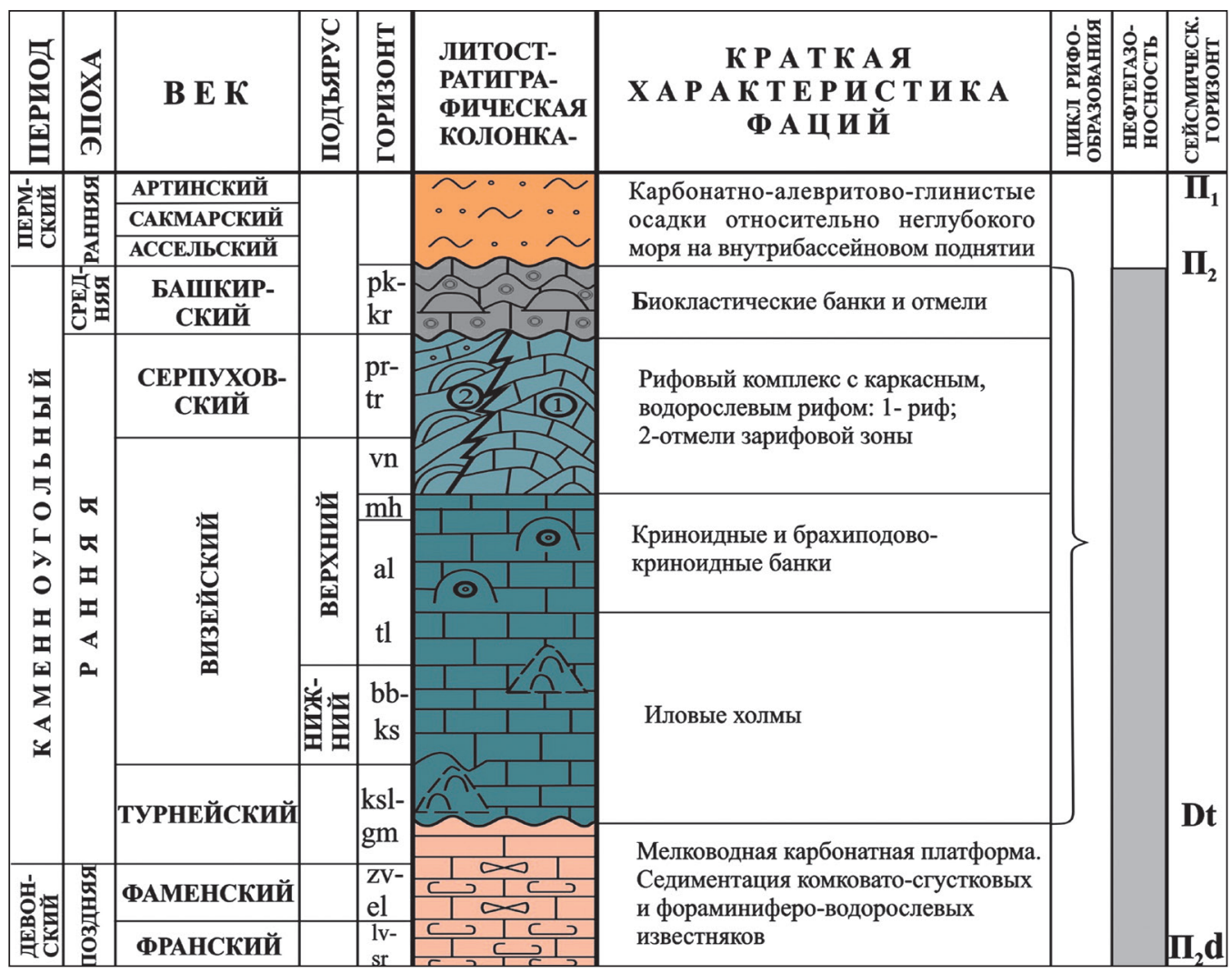

Рисунок 4 - Вертикальный фациальный ряд Тенгиз-Кашаганской карбонатной платформы (на примере Тенгизского месторождения)

личной плотностью, с прослоями аргиллитов. Стратиграфический объем толщи определяется окским, серпуховским, башкирским, раннемосковским возрастом. Формировалась толща в условиях мелководного морского бассейна на обширной территории всего восточного борат в виде карбонатной платформы. Вертикальный фациальный ряд северо-западной окраины Южно-Эмбинской карбонатной платформы приведен на рисунке 5.

В пределах Астраханской карбонатной платформы в поздневизейско-раннебашкирское время накапливались преимущественно мелководные карбонатные образования, а в более пониженных частях прогибов - глинисто-карбонатные, относительно глубоководные осадки. Области мелководной карбонатной седиментации сократились. В раннем башкире условия осадконакопления соответствуют лагунным обстановкам, в которых накапливались продукты разрушения рифовых построек. Отложения представлены биоморфными, биоморфно-детритовыми, биохемогенными и органогенно-обломочными известняками.

Московско-позднекаменноугольная седиментационная модель. Конец башкирского - начало московского веков ознаменовало начало третьего (позднебашкирско-раннегжельского) этапа в развитии карбонатных платформ, связанного 


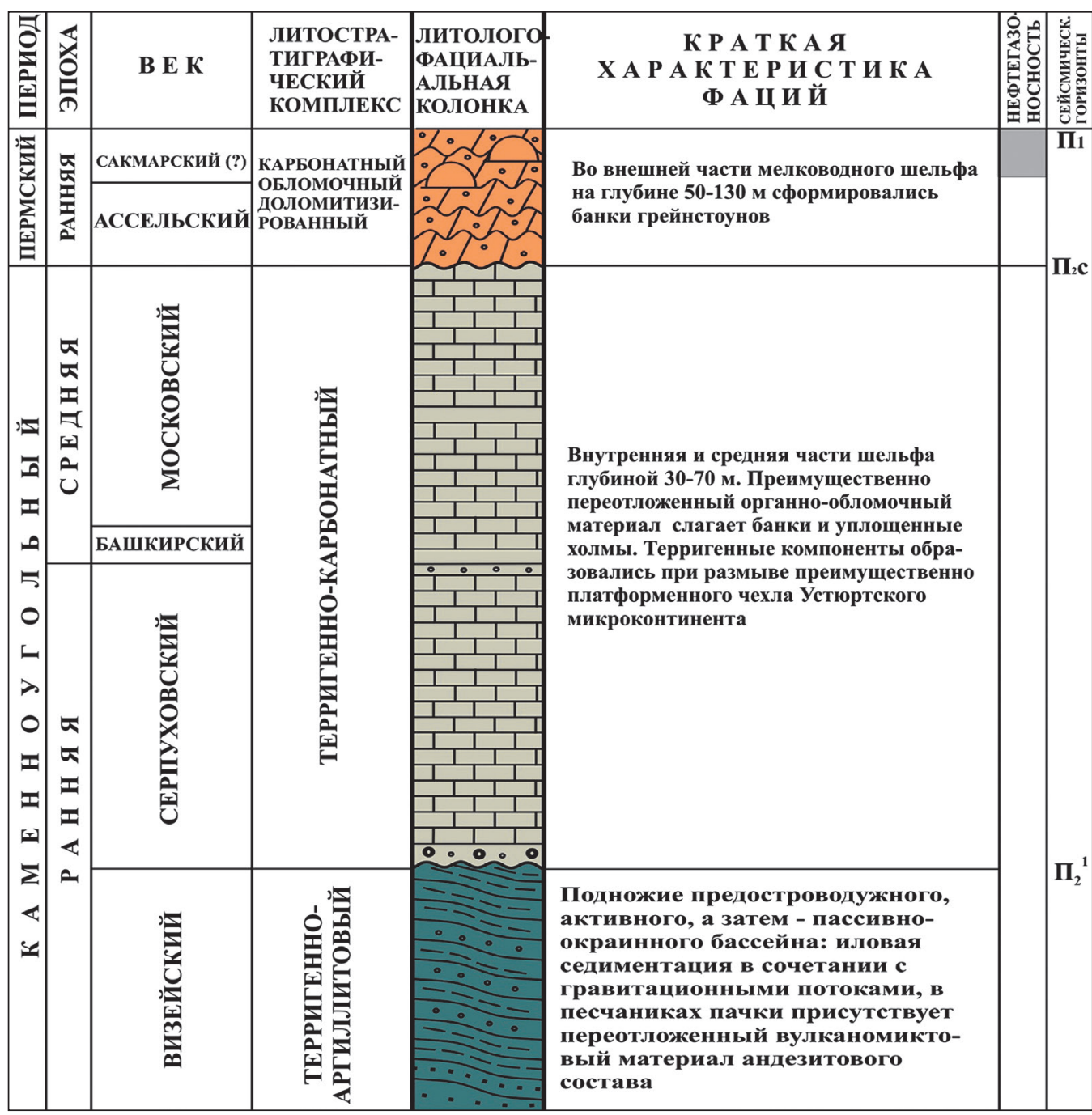

Рисунок 5 - Вертикальный фациальный ряд северо-западной окраины Южно-Эмбинской карбонатной платформы

с интенсивными тектоническими процессами на юге впадины - в области кряжа Карпинского, где начался процесс седиментации мощных терригенных толщ (рисунок 6).

Московский бассейн осадконакопления унаследовал характер режима седиментации от башкирского. В Тенгиз-Кашаганской зоне в этот период времени имел место перерыв в осадконакоплении. Карбонатные платформы длительное время оставались в мелководно-морских условиях, периодически осушались, что способствовало развитию карстовых процессов. Накопление терригенного комплекса сопровождалось конседиментационными деформациями сжатия и надвигания на Астраханскую карбонатную платформу и цепочку других карбонатных массивов юга Прикаспийского бассейна. 


\section{ГЕОЛОГИЯ}

Серпуховско-московская - шельфовая терригенно-карбонатная толща получила свое развитие в зоне сочленения с Южно-Эмбинским поднятием. Толща представлена разрезом скважин площадей Биикжал, Тортай, Ю.З.Улькентобе, Шолькара, Табынай, Кумшеты, Уртатау-Сарыбулак и др. Разрезы включают в себя осадки шельфа (аргиллиты, глины, алевролиты, мергели, силициты, радиоляриты, глинистые известняки и др.) серпуховского, башкирского и московского возраста. Отмечается преобладание известняков в верхних частях разрезов серпуховского, башкирского и московского возраста и уменьшение их в нижней. Общая мощность серпуховско-московской терригенно-карбонатной толщи на площади Биикжал - 174 м.

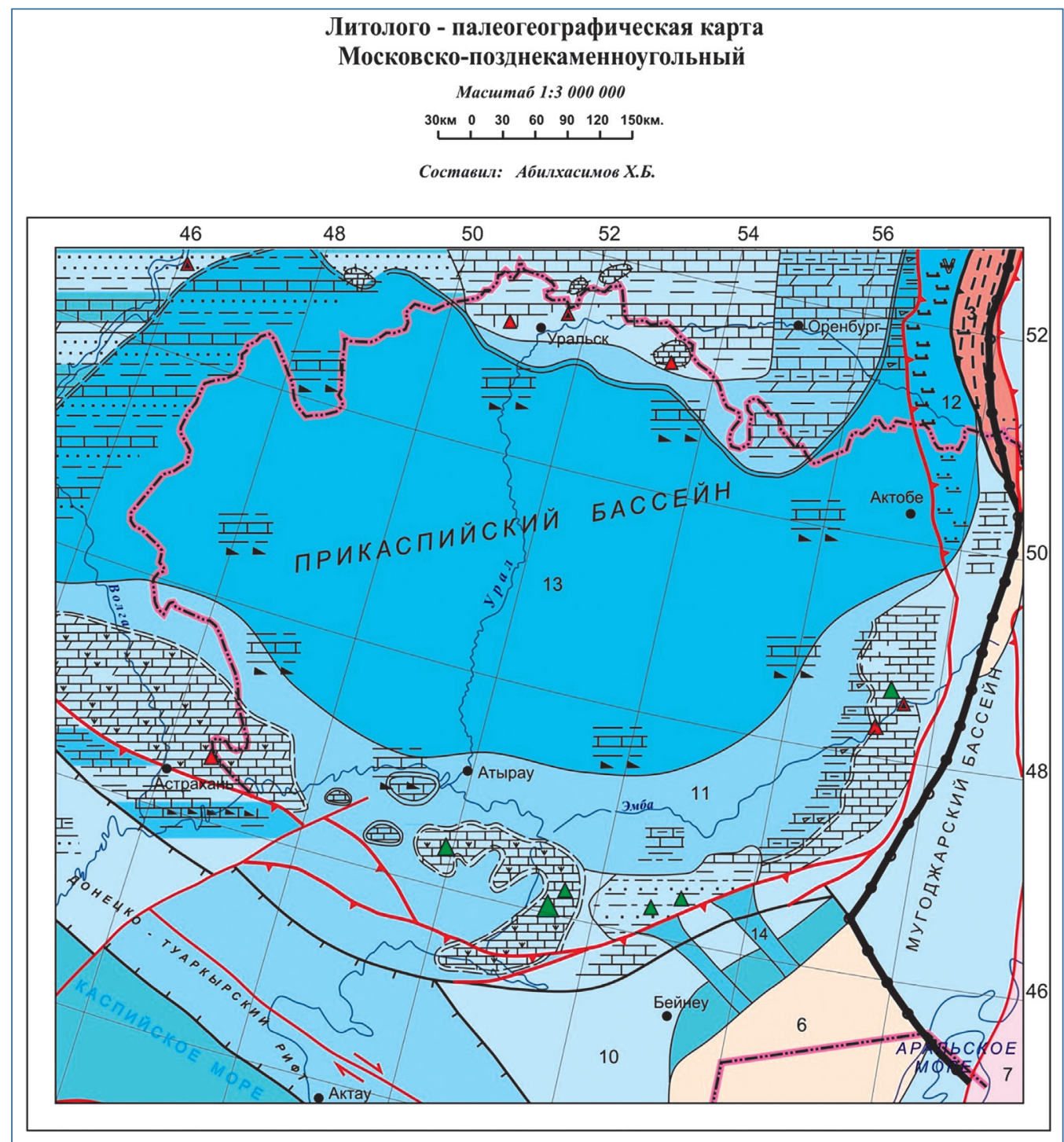

Рисунок 6 - Литолого-палеогеографическая карта московско-позднекаменноугольного этапа (условные обозначения на рисунке 9). Составил Х. Б. Абилхасимов 
Поздний карбон знаменуется резким падением уровня моря, что привело к частичному размыву ранее накопившихся отложений в области приподнятых участков и карбонатных построек: Тенгиз-Кашаганской и Южно-Эмбинской; сокращению зоны карбонатного шельфа, образованию подводных отмелей и повышению роли терригенного материала.

На Астраханской карбонатной платформе верхнекаменноугольные отложения сохранились фрагментарно из-за более позднего размыва. Здесь преобладают терригенно-обломочные и карбонатно-обломочные отложения. Мощность отложений составляет 180 - 250 м. Они вскрыты в скважинах 3-Высоковской, Южно-Астраханской и Табаковской-1. Перекрывается глинисто-карбонатной толщей нижней перми, представленной различными генетическими типами известняков светлой окраски различной структуры. Общая мощность сакмаро-артинских отложений - 225-330 м.

Ассельско-сакмарская седиментационная модель. В предпермское время Южно-Эмбинская карбонатная платформа развивалась, как и в предшествующий этап, со всем характерным платформе набором формаций. После длительного позднекарбонового перерыва в осадконакоплении и денудации положительных форм палеорельефа до глубины серпуховского, а иногда и визейского ярусов, произошла новая трансгрессия моря. Условия осадконакопления на юго-востоке Прикаспия в ассельском и сакмарском веках были сходные и, вероятно, составили единый цикл. Распределение литофациальных зон отложений ассельско-сакмарского возраста не претерпело существенных изменений по сравнению с позднекаменноугольным временем.

Карбонатонакопление сохранилось в узкой полосе на площади Уртатау-Сарыбулак (рисунок 7). Нижнепермские отложения представлены известняками светло-голубовато-серыми, биогермными, сочетающимися с голубовато-серыми, органогенно-детритовыми известняками, с сопутствующей фауной ассельского яруса. Мощность - 955 м. Мелководные осадки сменяются относительно глубоководными, развитыми в Маткен-Ушмолинской и в Тенгиз-Кашаганской зонах, где ассельские отложения залегают со стратиграфическим несогласием на разновозрастных образованиях карбона и представлены вулканогенно-осадочными образованиями.

Конец сакмарского - начало артинского века соответствует региональной перестройке всего тектонического режима в пределах рассматриваемой территории. Инверсия в области максимальной мощности накопившихся каменноугольных и ассельско-сакмарских отложений, привела к мощным восходящим движениям, сформировавшим на месте Южно-Эмбинского прогиба область с горным рельефом.

Артинская седиментационная модель. Заключительный артинский этап характеризуется горообразовательными процессами на Урале, т.е. появлением нового источника сноса терригенного материала в Прикаспийскую впадину. Кроме этого, продолжалась активная денудация выраженных в рельефе складок кряжа Карпинского. Формирование карбонатных платформ повсеместно прекращается за исключением центральных и южных частей Южно-Эмбинского поднятия (рисунок 8). Резкие падения уровня моря в изолированном Прикаспийском бассейне привели к выработке эрозионного рельефа в бортовых частях впадины и формированию мощных конусов выноса в юго-восточной части бассейна (Тортайский, Шолькаринский, Табынайский, Арман-Аиыршагыльский). Палеоруслаимеют пологую V-образную форму с широким 


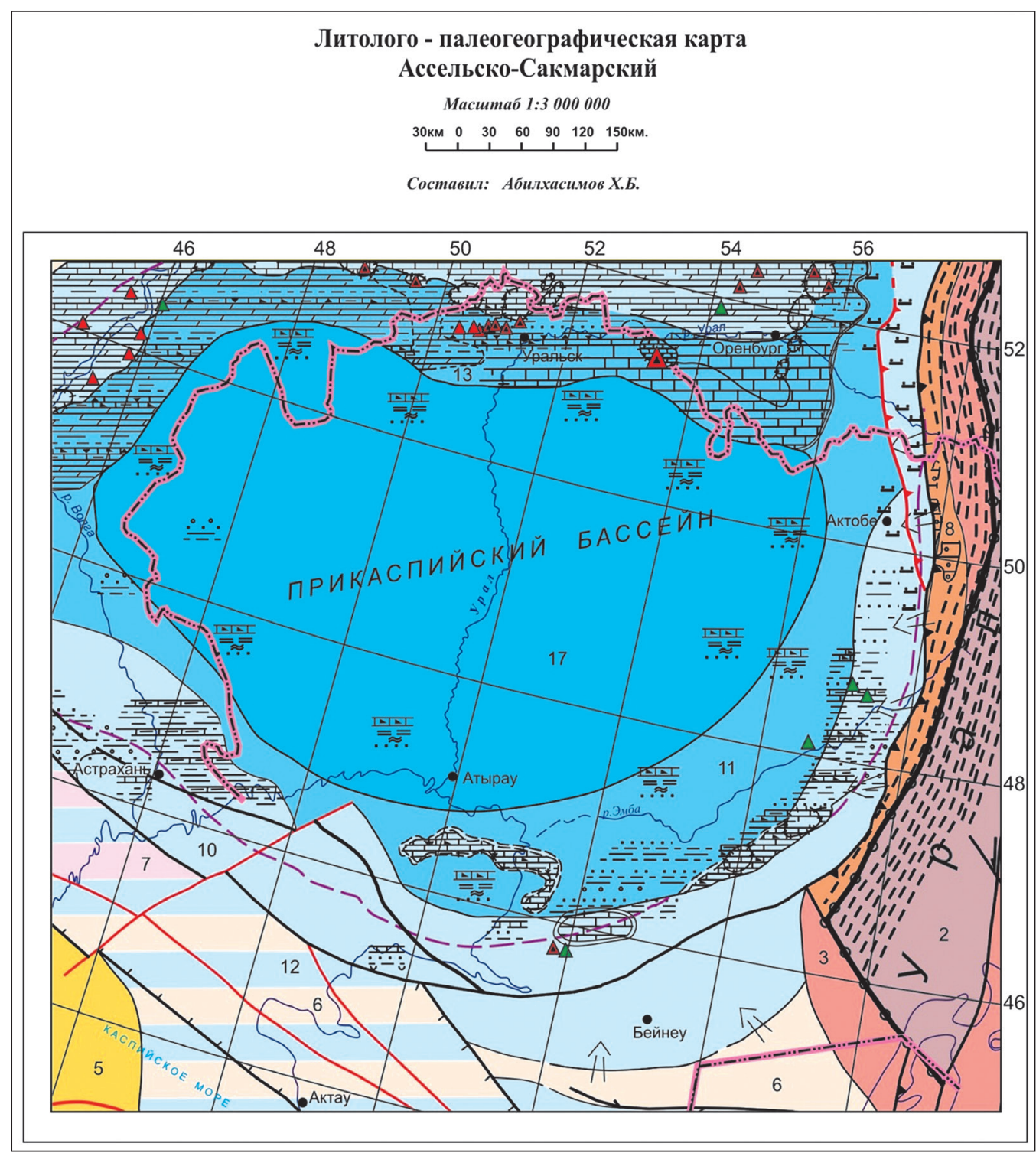

Рисунок 7 - Литолого-палеогеографическая карта ассельско-сакмарского этапа (условные обозначения на рисунке 9). Составил Х.Б. Абилхасимов

конусом, открытым в сторону бассейна и заполнены, в основном, средне-крупнозернистыми песками и гравием в различном соотношении, с большим количеством крупных остатков растительного детрита. В поперечном сечении в сторону от тальвега идет постепенное уменьшение гранулометрии осадков. Выделяются межрусловые и дамбовые осадки, представленные преимущественно мелкозернистым песком. В межрусловых западинах отлагается более тонкий глинистый материал. Грубозернистые русловые отложения занимают более широкую площадь, что связано с латеральной миграцией палеорусел за счет их меандрирования. 


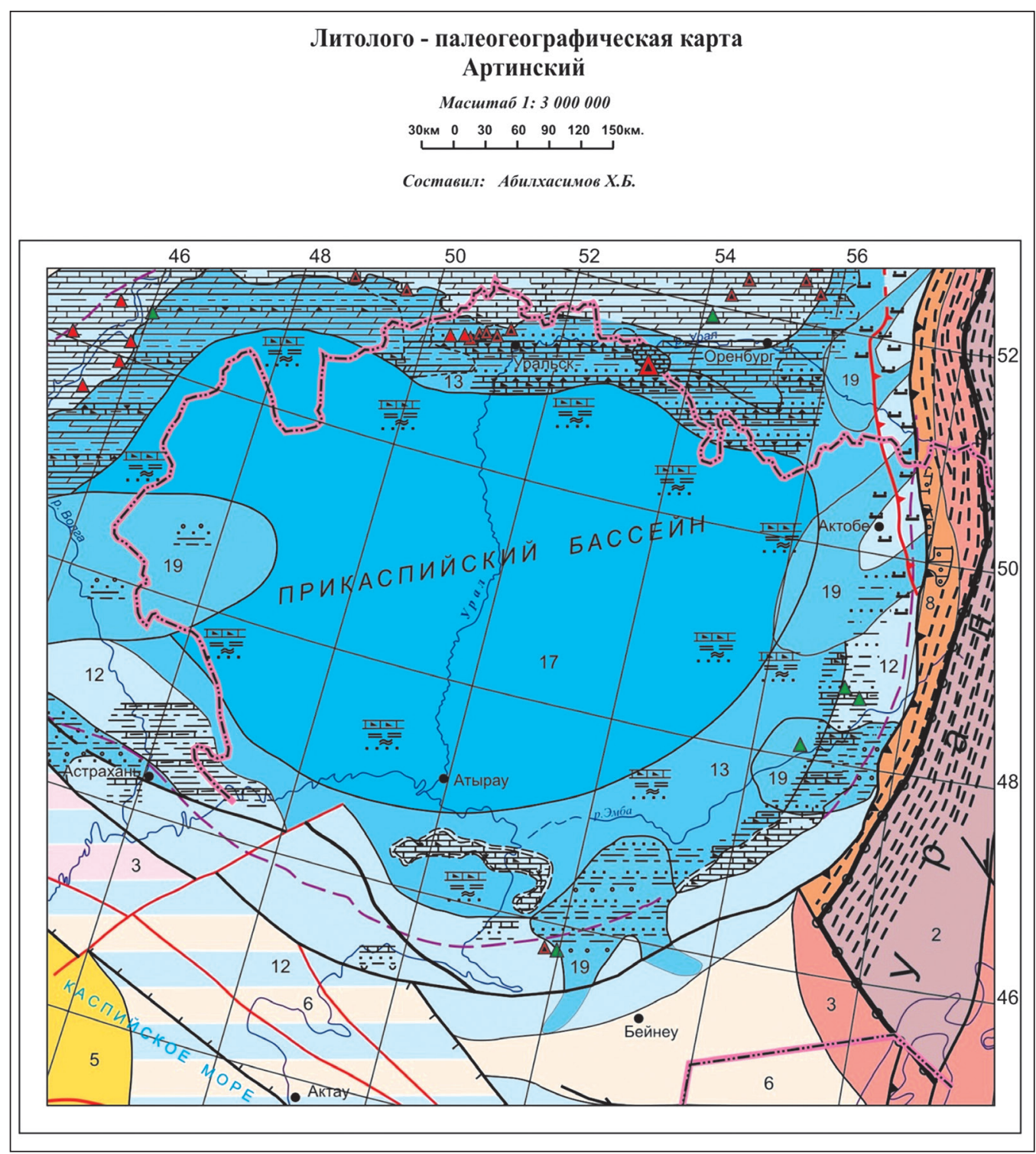

Рисунок 8 - Литолого-палеогеографическая карта артинского этапа (условные обозначения на рисунке 9). Составил Х.Б. Абилхасимов

Прослеживая границы седиментационных сейсмокомплексов и сейсмоформаций, удалось установить определенные закономерности в их размещении в пространстве и оценить вещественный состав отдельных сейсмоформаций. Основное отображение на временных разрезах находят такие элементы, как бортовые уступы шельфа, бровки шельфа, косослоистые и сигмоидальные формации бокового наращивания и конусов выноса, эрозионные и седиментационные уступы внутри бассейна, на склонах и у его подножия. В сводовых частях месторождений Тенгиз, Королевская, Тажигали мощность артинских отложений колеблется от первых метров до 255 м. Литологический 


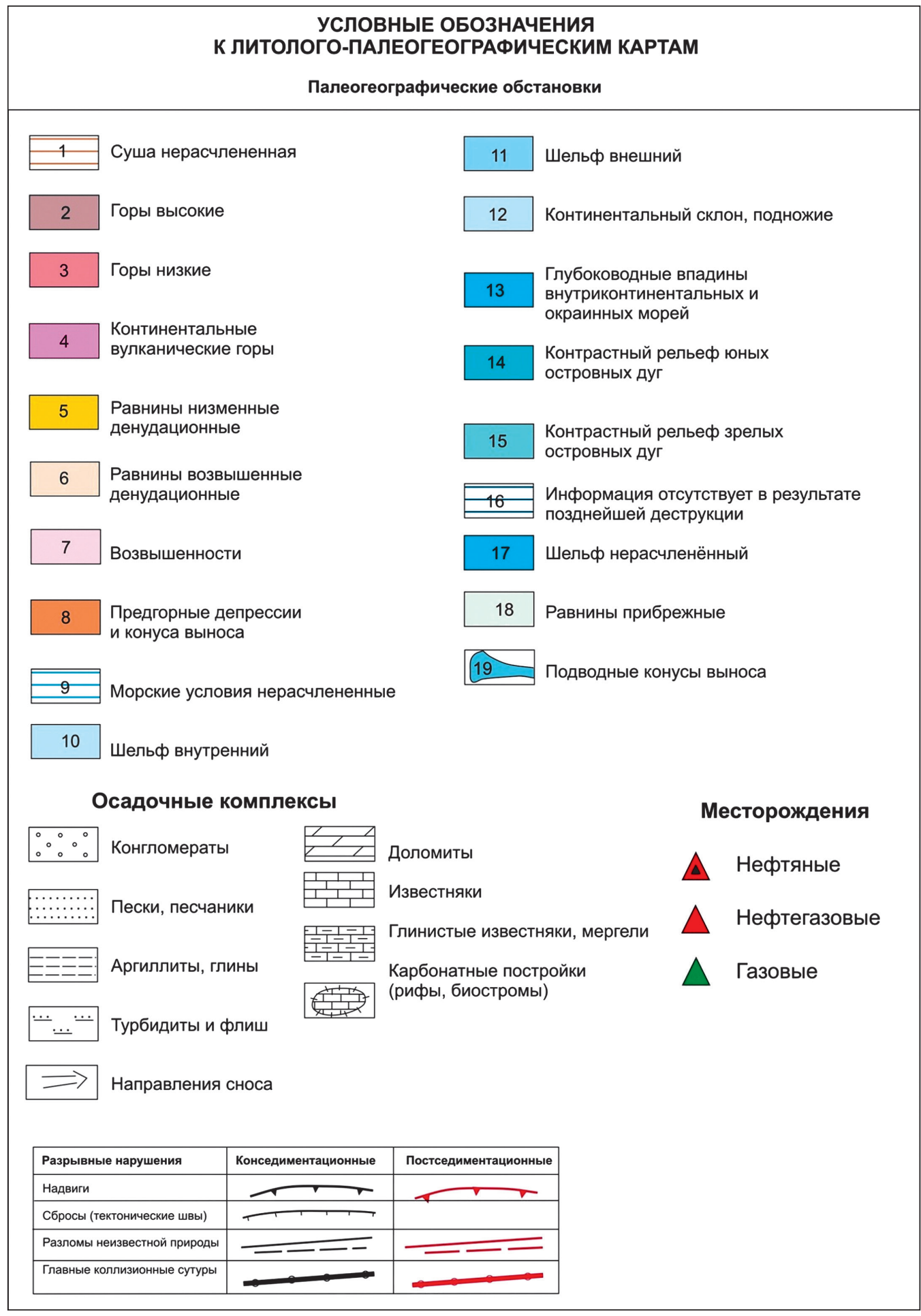

Рисунок 9 - Условные обозначения к литолого-палеогеографическим картам 
состав характеризуется преобладанием в разрезе аргиллитов, присутствием аргиллитоподобных глин, мергелей и известняков. Характерная особенность - площадное развитие туфопелитов и литовитрокластических туфов в нижней части разреза. В основании толщи выделяется горизонт глинисто-карбонатной брекчии. Туфогенные породы встречены в виде отдельных прослоев преимущественно светло-зеленой окраски $[11,12]$. Породы плотные, крепкие, с массивной текстурой, с раковистым изломом. По минеральному составу глинистого вещества в этих породах выделяются два подтипа. Первый - в основном туфопелиты, преимущественно гидрослюдисто-каолинитового состава с примесью смешаннослойных образований. Второй имеет мономинеральный состав из смешаннослойных образований гидрослюда - смектит. На северо-восточном крыле Тенгизской структуры в скважине 10 под кунгурской соленосной толщей в интервале 4862-4920 разрез представлен переслаиванием глинистых пород с прослоями алевролитов и мергелей. Глинистые породы представлены преимущественно аргиллитами известковистыми, в различной степени битуминозными, алевритистыми, тонко-горизонтально-слоистыми, с большим количеством обугленного растительного детрита, рассеянным и мелкоагрегатным глобулярным пиритом. В отдельных прослоях (4912-4913 м) отмечаются скопления остатков кремневых скелетов радиолярий, характерных для верхов карбона или нижней перми (асселя).

Особенностью обстановки осадконакопления в позднепалеозойском бассейне Прикаспия является то, что в пределах единого бассейна сложились различные геоморфологические уровни осадконакопления. Карбонатные платформы слагают изолированные участки, фиксируемые положительными формами рельефа палеодна $[5,8,13]$.

Характерным для этого этапа седиментации является формирование мощных конусов выноса, языки которых проникали во внутреннюю часть бассейна, образуя в разрезах грубообломочные прослои, а также межконусовые подводные аккумулятивные валы, преимущественно, глинистого состава с подчиненными прослоями песчаников, реже гравелитов. Особую роль играют палеорусловые системы, которые являлись основными артериями при поставке терригенного материала в бассейн. В дистальных частях бассейна преобладают преимущественно терригенные отложения. Морфологические неровности палеодна распознаются по гранулометрии осадков. На приподнятых участках - сводах - накапливается, в основном, глинисто-алевритовый материал. В пониженных частях, в зонах с большими скоростями донных течений, из-за вымывания глинистой фракции концентрируется более грубый материал -псаммитовый.

К концу артинского времени Прикаспийский осадочный бассейн был ограничен с юго-запада континентальным Скифским блоком и Северо-Устюртским массивом - с юго-востока, что подтверждается покровно-надвиговыми деформациями в области кряжа Карпинского и Донбасско-Астраханской зоны. В изолированном Прикаспийском бассейне в кунгуре в спокойной тектонической обстановке накапливались мощные толщи соли.

\section{ВЫВОДЫ:}

Обобщая данные об обстановках осадконакопления палеозоя, следует отметить, что:

- Пространственное размещение карбонатных платформ в Прикаспийской впадине определяется различной продолжительностью этапов седиментации и блоковой структурой фундамента. 
• В юго-восточной части Прикаспийской впадины за счет влияния геодинамических факторов сближения Урала и Северо-Устюртского блока с краем Восточно-Европейской плиты, области карбонатонакопления резко сократились и образовалась Южно-Эмбинская карбонатная платформа. Процессы карбонатонакопления подавлялись привносом большого количества терригенного материала с прилегающей суши.

• Южно-Эмбинская карбонатная платформа значительно моложе Тенгиз-Кашаганской. Карбонатные отложения в ее пределах занимают более узкий стратиграфический интервал, охватывающий период с конца нижнего карбона - раннего визе до ассель-сакмарского яруса нижней перми включительно.

- Наиболее интенсивное карбонатонакопление протекало на юге и юго-западе Прикаспия в пределах Астраханской и Тенгиз-Кашаганской платформ; за счет расширения площади карбонатонакопления в позднем девоне образовалась единая Астраханско-Жылыойская платформа, которая охватывала всю современную акваторию Северного Каспия и прилегающие к ней прибрежные участки.

- Единая Астраханско-Жылыойская девонская карбонатная платформа, в пределах которой расположено поднятие Южное, оконтуривается по прослеживанию ее цоколя между региональными отражающими горизонтами $\Pi_{3}$ и $\Pi_{4}$. Предполагаемый возраст карбонатов, заключенных между этими горизонтами, средний - нижний девон. На этом цоколе происходил рост четко выраженных на сейсмических профилях рифогенных построек - атоллов: Тенгизкое, Каратон, Пустынная, Тажигали, Кашаган, Актоты,и других верхнедевонско-артинского возраста.

- Наряду с указанными атоллами здесь присутствуют менее рельефно выраженные карбонатные постройки верхнедевонско-башкирского возраста, такие как Ансаган и Аманат, закартированных к востоку и северу от известного гигантского месторождения Тенгиз.

- Юго-восточный удаленный источник сноса, судя по разрастанию толщин карбона и перми в южном направлении, поставлял в это время значительное количество преимущественно глинистого материала нивелируя Маткенский прогиб, примыкающий с востока к карбонатной платформе.

- В процессе замыкания кунгурского бассейна и образования его южного борта, наклон дна бассейна по направлению на север увеличился, что соответственно привело к внутриформационным срывам в терригенной нижнепермско-карбоновой толще и образованию «бескорневых» структур Пионерская, Култук Северный, Юбилейная и др. Закономерным является то, что такие структуры образовались только восточнее границы карбонатной платформы и краевых рифов, которые на момент накопления толщ, образовавших складки, явились барьером для проникновения больших масс терригенного материала в пределы карбонатной платформы.

- Одна из особенностей формирования рифовых массивов в данном регионе, выявленная многими исследователями - это дугообразное строение биогермов, выпуклая сторона которых обращена на северо-восток, откуда продолжительное время происходило океаническое течение.

- Участок, на котором расположены карбонатные постройки Максат, Огайская, на протяжении большого периода геологического времени находился на более высоком гипсометрическом уровне, чем окружающая его территория. Большинство рифов в 
данном районе прекратили свой рост в башкирское время среднего карбона, а Южная росла вплоть до артинского яруса, пермского периода времени. При падении уровня мирового океана кровля рифа выходила на дневную поверхность, что приводило к эрозии его кровли. Продукты эрозии сформировали в артинское время на карбонатной платформе карбонатно-терригенную брекчию, перекрывающую более погруженные рифовые постройки и входящую в непосредственный контакт со склонами рифа Тенгиз.

- Астраханская карбонатная платформа связана с формированием на вулканическом поднятии ограниченного по площади карбонатного массива высотой до 500 м, располагавшегося вдоль северо-восточного края платформы.

\section{ЛИТЕРАТУРА}

1 Замаренов А.К., Шебалдина М.Г., Федоров Д.Л., Югай Т.А., Яцкевич С.В. Седиментационные модели подсолевых нефтегазоносных комплексов Прикаспийской впадины. - М.: Недра, 1986. - 137 с. [Zamarenov A.K., SHebaldina M.G., Fedorov D.L., Yugaj T.A., Yackevich S.V. Sedimentacionnye modeli podsolevyh neftegazonosnyh kompleksov Prikaspijskoj vpadiny. - M.: Nedra, 1986. - 137 s.]

2 Астраханский карбонатный массив: Строение и нефтегазоносность. Под редакцией Ю.А.Воложа, В.С.Парасыны. - М.: Научный мир, 2008. - 221 с. [Astrahanskij karbonatnyj massiv: Stroenie i neftegazonosnost'. Pod redakciej Yu.A.Volozha, V.S.Parasyny. - M.: Nauchnyj mir, 2008. - 221 s.]

3 Жолтаев Г.Ж., Абилхасимов Х.Б. Седиментационные модели и перспективы нефтегазоносности палеозойских отложений Прикаспийской синеклизы и Устюрта // Геология регионов Каспийского и Аральского морей: - Алматы: Казахстанское геологическое общество «КазГЕО», 2004. -472. с. 296-306. [Zholtaev G.Zh., Abilhasimov H.B. Sedimentacionnye modeli i perspektivy neftegazonosnosti paleozojskih otlozhenij Prikaspijskoj sineklizy i Ustyurta //Geologiya regionov Kaspijskogo i Aral'skogo morej: Almaty: Kazahstanskoe geologicheskoe obshchestvo «KazGEO», 2004. -472. s. 296-306.]

4 Ескожа Б.А., Аймагамбетов М.У., Исмагулова С.А. Роль процесса осадконакопления в формировании ловушек нефти и газа в позднем палеозое Прикаспийской впадины // Нефть и газ. - 2019. - №2. - C. 43-61. [Eskozha B.A., Ajmagambetov M.U., Ismagulova S.A. Rol' processa osadkonakopleniya $v$ formirovanii lovushek nefti i gaza $v$ pozdnem paleozoe Prikaspijskoj vpadiny // Neft' i gaz. - 2019. - №2. - S. 43-61.]

5 Абилхасимов Х.Б. Тектоно-седиментационная модель строения и оценка нефтегазоносности палеозойского комплекса юго-востока Прикаспийской синеклизы. - М.: ООО «Геоинформцентр», 2003. - 115 с. [Abilhasimov H.B. Tektono-sedimentacionnaya model' stroeniya i ocenka neftegazonosnosti paleozojskogo kompleksa yugo-vostoka Prikaspijskoj sineklizy. - M.: OOO «Geoinformcentr», 2003. - 115 s.]

6 Абилхасимов Х.Б. Закономерности пространственного размещения природных резервуаров Прикаспийской впадины. «Геология нефти и газа». - М: ООО «Геоинформцентр», 2007. - C. 11-18. [Abilhasimov H.B. Zakonomernosti prostranstvennogo razmeshcheniya prirodnyh rezervuarov Prikaspijskoj vpadiny. «Geologiya nefti i gaza». - M: OOO «Geoinformcentr», 2007. - S. 11-18.]

7 Абилхасимов Х.Б. Геодинамические и седиментационные этапы эволюции юго-востока Прикаспийской синеклизы в палеозое. «Геология, ресурсы, перспективы освоения нефттегазовых недр Прикаспийской впадины и Каспийского региона». Международная научно-техническая конференции: Оценка перспектив нефтегазоносности верхнепалеозойских отложений юго-востока Прикаспийской синеклизы. Избранные доклады / под ред. Гаврилова В.П. - М.: МАКС Пресс, 2008. - С. 17-27. [Abilhasimov 
H.B. Geodinamicheskie i sedimentacionnye etapy evolyucii yugo-vostoka Prikaspijskoj sineklizy v paleozoe. "Geologiya, resursy, perspektivy osvoeniya neftegazovyh nedr Prikaspijskoj vpadiny i Kaspijskogo regiona». Mezhdunarodnaya nauchno-tekhnicheskaya konferencii: Ocenka perspektiv neftegazonosnosti verhnepaleozojskih otlozhenij yugovostoka Prikaspijskoj sineklizy. Izbrannye doklady / pod red. Gavrilova V.P. - M.: MAKS Press, 2008. - S. 17-27.]

8 Абилхасимов Х.Б. Особенности формирования природных резервуаров палеозойских отложений Прикаспийской впадины и оценка перспектив их нефтегазоносности. М.: Издательский дом Академии Естествознания, 2016. - 244 с. [Abilhasimov H.B. Osobennosti formirovaniya prirodnyh rezervuarov paleozojskih otlozhenij Prikaspijskoj vpadiny i ocenka perspektiv ih neftegazonosnosti. - M.: Izdatel'skij dom Akademii Estestvoznaniya, 2016. - 244 s.]

9 Мусагалиев М. З., Панкратов В.Ф., Куанышев Ф.М., Пронин А.П. Эволюция верхнепалеозойских карбонатных платформ юга Прикаспийской впадины // Геология и охрана недр. - 2004. - № 11. [Musagaliev M. Z., Pankratov V.F., Kuanyshev F.M., Pronin A.P. Evolyuciya verhnepaleozojskih karbonatnyh platform yuga Prikaspijskoj vpadiny // Geologiya i ohrana nedr. - 2004. - № 11.]

10 Атлас литолого-палеогеографических, структурных, палинспатических и геоэкологических карт Центральной Евразии. - Алма-Ата, 2002. [Atlas litologo-paleogeograficheskih, strukturnyh, palinspaticheskih i geoekologicheskih kart Central'noj Evrazii. - Alma-Ata, 2002.]

11 Рихтер Я. А., Пронин А. П. Раннекаменноугольный вулканизм на юго-востоке Прикаспийской впадин // Известия Саратовского университета. Новая серия. Серия: Науки о Земле. - 2015. - Т. 15. - Вып. 4. - С. 55-66. [Rihter Ya. A., Pronin A. P. Rannekamennougol'nyj vulkanizm na yugo-vostoke Prikaspijskoj vpadin // Izvestiya Saratovskogo universiteta. Novaya seriya. Seriya: Nauki o Zemle. - 2015. - T. 15. - Vyp. 4. - S. 55-66.]

12 Пилифосов В.М., Воцалевский Э.С., Азербаев Н.А., Пронин А.П. Проблема палеозойского вулканизма юга Прикаспийской впадины // Геология Казахстана. - 1997. - № 1. - C. 4-10. [Pilifosov V.M., Vocalevskij E.S., Azerbaev N. A., Pronin A. P. Problema paleozojskogo vulkanizma yuga Prikaspijskoj vpadiny // Geologiya Kazahstana. - 1997. - № 1. - S. 4-10.]

13 Гаврилов В. П., Леонова Е. А., Руднев А. Н. Геодинамическая модель геологического строения и нефтегазоносности Прикаспийской впадины // Геология нефти и газа. 2009. - № 3. - C. 2-10. [Gavrilov V. P., Leonova E. A., Rudnev A. N. Geodinamicheskaya model' geologicheskogo stroeniya i neftegazonosnosti Prikaspijskoj vpadiny // Geologiya nefti i gaza. - 2009. - № 3. - S. 2-10.] 